\title{
The Impact of Servant Leadership on Follower Turnover Intentions: Mediating Role of Resilience
}

\author{
Norizah Mustamil* and Usama Najam
}

\begin{abstract}
Manuscript type: Research paper

Research aims: This paper aims to investigate the impact of servant leadership on turnover intentions within the context of higher education institutions (HEIs). It further examines how resilience affects the relationship between the two variables.

Design/Methodology/Approach: Based on the conservation of resource theory, a research model has been developed and tested through a questionnaire survey approach. Data collected from 301 academics in HEIs in Pakistan were analysed using covariance-based structural equation modelling.

Research findings: The study provides empirical evidence on the importance of having leaders who administer servant leadership, as this will help to reduce the turnover intention. It also reports the mediating effect of employee resilience.

Theoretical contribution/Originality: This study expands the previous literature by focussing on the servant leadership type, which has potentially led to positive followers' behaviour. It also fills the research gap by incorporating employee resilience as a mediating variable.
\end{abstract}

* Corresponding Author: Norizah Mustamil is an Associate Professor at the Department of Business Policy and Strategy, Faculty of Business and Accountancy, University of Malaya. Email: norizahmm@um.edu.my

Usama Najam is a PhD Scholar at the Department of Business Policy and Strategy, Faculty of Business and Accountancy, University of Malaya. Email: usama@aumc.edu.pk

Acknowledgement: This research was funded by the Geran Penyelidikan Fakulti 2019 (GPF), "Servant Leadership Style: A Curse or Blessing for Leader Himself?"

https://doi.org/10.22452/ajba.vol13no2.5 
Practitioner/Policy implication: Principals, directors and vicechancellors of HEIs should reconsider their leadership strategies to promote a positive working environment, as this will help to address the problem of employee turnover.

Research limitation/Implication: Since the data were collected from Pakistan, it may not be possible to generalise the findings.

Keywords: Employee Retention, Sustainability, Servant Leadership, Resilience, Turnover Intention

JEL Classification: M100

\section{Introduction}

Today's competitive environment demands organisations to be sustainable, proactive, visionary and able to foresee the future. Organisations rely on their capacity to retain employees in order to sustain themselves, because human capital appears to be a dynamic resource of today's world. Replacing employees not only can be costly, it also leaves the organisation perpetually shorthanded, and in some cases, it may disrupt the project's deadlines or client expectations (Jo, 2008). High turnover may also lead to resentment among existing employees, as they have to pick up the slack for slower and less experienced workers. In Asia, it was reported that there was a sharp decline in the working population from 2015 to 2020 (e.g. from 72.6 per cent to 59.7 per cent for China; 73.1 per cent to 53.2 per cent for South Korea; and 71.4 per cent to 58.0 per cent for Thailand) (International Labour Organization, 2019). This shows that the war for talent has risen in Asia, challenging the business sustainability.

In the education sector, retention of employees is crucial since the academics are the most valuable asset for HEIs (Khalid, Irshad, \& Mahmood, 2012). Unlike before, HEIs are now not only expected to produce holistic and capable graduates, they are also required to engage in high-quality research. Moreover, with an increase in student enrolment, the needs for internalisation and limited funding, employees in the higher education sector are under stress, causing them to develop turnover intentions (Ismail \& Arma, 2016). According to McGonagle, Fisher, Barnes-Farrell, and Grosch (2015), employees leave the organisation mostly because of internal factors. Among these factors, 75 per cent of voluntary turnover is influenced by the leaders of HEIs (Beck \& Harter, 2015). This is in line with some of the empirical 
work conducted in this field, which highlighted leadership as the prime factor (Majeed, Ramayah, Mustamil, Nazri, \& Jamshed, 2017; Kashyap \& Rangnekar, 2016; Liu, Cai, Li, Shi, \& Fang, 2013). A good leadership style could improve organisational performance by helping to empower human resource, promote innovation and learning and enable change. Despite the existing evidence relating leadership style and employees' behaviours, research in this area has not been fully exploited.

In the leadership literature, the studies have related the servant leadership to engaged and committed employees, as it captures the personal integrity and social responsibility that is deemed lacking in other traditional style of leadership (De Clercq, Bouckenooghe, Raja, \& Matsyborska, 2014). They highlighted that, within the academic line, servant leadership is best fitted to organisational values than any other type of leadership. Despite the existence of studies that demonstrated the link between servant leadership style and employees' behaviours, the strength of the effects was reported to be varied. On one hand, strong correlations were identified in some studies (e.g. Ling, Lin, \& $\mathrm{Wu}, 2016)$, whilst, on the other hand, some research suggested far weaker relationships (Neubert, Hunter, \& Tolentino, 2016), limiting our understanding of servant leadership styles (Brohi, et al., 2018; Eva, Robin, Sendjaya, van Dierendonck, \& Liden, 2019).

Motivated by this gap, this study aims to examine the impact of servant leadership on the turnover intentions of employees in the Pakistan HEIs. It attempts to expand the previous literature by investigating the employee resilience as the mediating variable. The higher education sector in Pakistan is growing with the establishment of 170 universities and 1.3 million students (Ministry of Finance, Government of Pakistan, 2016). Over the years, this sector faces business challenges like any other industry in the country's economy. To survive, universities need to consider ways to develop their leaders, and also the appropriate measures to apply in order to adopt the most suitable leadership behaviour for the respective institutions. In view of this, it is imperative to investigate the issue in the context of Pakistani's HEIs.

This paper comprises of six sections. Section 2 highlights the literature reviewed and discusses the hypotheses development. Section 3 explains the methodologies employed. Section 4 presents and discusses the research findings and Section 5 concludes the study by discussing the implications and limitations of this study. 


\section{Literature Review}

\subsection{Theoretical Background and Hypotheses Development}

This study is based on the Conservation of Resources (COR) theory (Hobfoll, 2011). This theory contests employees' strive to acquire and conserve their valued resources from any future potential threats in order to sustain them. There are four basic principles of COR theory. The first principle argues that the loss of resources is disproportionately more striking than the resource gain. The second principle puts forward a proposition that people must invest in resources to cope with resource loss and to gain new resources. The third principle states that, in the presence of resource loss, the value of resource gain is more completely understood. The fourth principle argues that people who are under deficiency of resources become irrational, and thus may behave aggressively or activate their defensive mode. These valued resources can include personal resources (e.g., personality characteristics, physical or psychological energies) as well as organisational resources (e.g., employer or boss support, rewards or recognition).

This paper employed the COR theory to understand the servant leadership's potential impact on his/her followers. A leader commonly has an abundance of valuable resources (Ye, Lyu, \& He, 2019), and in the context of servant leadership, servant leaders will attempt to provide their followers with resources that would facilitate their jobs and personal development. Learning opportunities and supportive workplace atmosphere are among the resources that are looked upon by the followers. With these resources, they would experience high level of commitment and engagement towards the job, and be more willing to reinvest their resources (e.g. time, expertise) to create gain cycles. Accordingly, this will lead to a low turnover intention. Such amount of resources would also stimulate employees to dedicate themselves to the work with mental resilience. At the workplace, there are numerous factors that can cause job strains. These job strains cause the threat of resource loss or actual loss and are responsible for employee turnover intentions (Harris, Harris, \& Harvey, 2008). Without a servant leadership styles, employees may not feel that they have a support system to minimise the perceived resource losses. In this situation, they will also have low resilience level to fight and cope with the undesired event, leading to turnover intention. Given the above arguments, we include servant leaderships, employee resilience and turnover intention in our research model. The following sections highlight the hypotheses. 


\subsubsection{Servant Leadership and Employee Turnover Intention}

The term servant leadership was first coined by Greenleaf (1977), who defined the term as a leadership style that is not only practiced to lead an organisation, but is seen as a way of living that starts with the intention of focussing on the psychological needs of followers and places the organisational goals as secondary (Ice, 2017). As it engages followers from multiple dimensions, such as relational, ethical, emotional, spiritual and authentic, this leadership style is considered as a holistic leadership. Servant leaders help their employees grow to their maximum capability by empowering them. The prime motive of servant leader is to serve his/her followers in order to improve them (Greenleaf, 1977). They strive to obtain the followers' resources that are required for the work and to keep employees psychologically fit. Unlike the other types of leadership, which are more performance/goal oriented, servant leadership does not sacrifice people over short-term profits or organisational goals. Instead, it focusses on achieving sustainable long-term performance that is attained through investment in human capital (Sendjaya, 2015). Thus, it is not surprising that the servant leadership appears to be synonymous with those who seek opportunity and empowerment.

In an earlier meta-analysis study on turnover intention, Griffeth, Hom and Gaertner (2000) suggested that leadership style plays a key role in reducing employee turnover intentions. Research has predicted that having a servant leadership style will lead to less turnover intentions among employees. For instance, Parris and Peachey (2013) described servant leadership style as a way in which a leader forgo his/her personal interest and works altruistically for advantage and betterment of followers. Due to this characteristic, servant leadership has shown a positive impact on followers' needs for achievement, growth and empowerment (Coetzer, Bussin, \& Geldenhuys, 2017; Schwarz, Newman, Cooper, \& Eva, 2016). In the service sector, Wongboonsin et al. (2018) proposed that support from leaders would help cushion strain, role stress and role conflict that would eventually improve emotional health of an employee. At the organisational level, employees perceive support from leaders as a representative of organisational support, which then leads to lower turnover rates. Hence, although employees are confronted with multiple work demands that could strain them, they would not be overwhelmed by a feeling of helplessness, with the existence of servant leaders. Based on these arguments, the following hypothesis was formulated: 
$\mathrm{H}_{1}$ : Servant leadership is negatively related to employees' turnover intention.

\subsubsection{Servant Leadership and Employee Resilience}

In the organisational behaviour context, resilience is referred to as the employees' ability to adapt and learn from the dynamic and changing working environment (Bhamra, Dani, \& Burnard, 2011). Resilient employees use the work resources to cope with the organisational environment challenges by ensuring continuous development and growth (Nguyen, Kuntz, Näswall, \& Malinen, 2016). Whilst there has been a significant growth in the last decade on the concept of resilience in the field of psychology, this concept is still new in organisational behavioral research (Othman, Ghazali, \& Nasurdin, 2017; Othman \& Nasurdin, 2011). Resilient workers possess a strong feeling of loyalty and enormous tendency to improvise themselves (Cooper, Liu, \& Tarba, 2014). Due to these characteristics, it is not surprising that having employees with resilience capital can be an utmost important resource for organisations, as this would help in coping with the negative events at the workplace or even from personal setbacks. Resilient employees have the endurance to deal with disruptive forces at the workplace and to harness their feelings to pursue alternative employment opportunities (Harris et al., 2008).

Employee who is resilient however, relies on the resources provided by the organisations. These resources can be affected by numerous factors, including leadership styles (Chen, Westman, \& Hobfoll, 2015). Numerous studies had highlighted that the servant leadership could enhance the employee resilience as servant leaders, commonly placing their followers' concerns ahead of organisational goals and even their personal interests (Barbuto \& Gottfredson, 2016; Barbuto, Gottfredson, \& Searle, 2014; Barbuto \& Wheeler, 2006; Walumbwa, Hartnell, \& Oke, 2010). The leaders' traits, attitudes and skills such as empathy, humility, and empowerment are positively linked towards the development of one of the most important components of psychological capital that is employee resilience (Ice, 2017; Liden, Wayne, Zhao, \& Henderson, 2008). Liden et al. (2008) argued that prioritising the growth and development of subordinates could cause the employees to have better coping mechanisms in order to withstand organisational and personal stressors. In a more recent study conducted by Knani, Fournier and Biron (2018), non-work instrumental support, such as providing child care services, 
was found to potentially reduce emotional exhaustion as a result of competing demands and family commitments. Such resources help the employees to perform their work with a peaceful mind and reduce their pressure due to increased responsibility. Based on these arguments, the following hypothesis was formulated:

$\mathrm{H}_{2}$ : Servant leadership is positively related to employee resilience.

\subsubsection{Employee Resilience and Turnover Intention}

The occurrence of adverse events and personal setbacks for an employee within an organisation is inevitable. It is more than ever needed for employees to have high resilience in today's dynamic and competitive work environment. Employee resilience works as a coping mechanism to counter the adversity that employees face at work. Employees with a high level of resilience are best equipped to deal with stressors. This is because resilient employees are characterised as being highly open, flexible and welcoming to change and show tremendous amount of emotional stability (Cooper et al., 2014). Significant studies have established psychological capital such as resilience as a significant predictor for reducing employee stress level, enhancing organisational commitment, performance and satisfaction (Cooper et al., 2014; Luthans, Luthans, \& Luthans, 2004). In this context, Coomber and Barriball (2007) found that stress and workplace adversities have been the leading cause for employee intention to leave. Based on these arguments, the following hypothesis was formulated:

$\mathrm{H}_{3}$ : Employee resilience is negatively related to employee turnover intention.

\subsubsection{Employee Resilience as a Mediator between Servant Leadership and Employee Turnover Intentions}

Based on the COR theory, servant leaders are perceived as significant initiators of a process of resource crossover, which enhance the employee resilience at the workplace (Hobfoll, Halbesleben, Neveu, \& Westman, 2018). The servant leader gives priority to his/her employees by providing them with a supportive environment that would empower and enhance their competencies (Walumbwa et al., 2011). When a leader shares his/her resources with his/her followers, this would lead to a perceived resource gain on the follower's end. Followers 
(employees), under such a leader will feel resourceful and further invest these resources in order to gain additional resources (Hobfoll, 2011). Resourceful followers invest these resources in gaining new resources, ultimately enhancing psychological capital, such as resilience. On the contrary, employees who are working under a leader who is abusive, non-supportive and authoritative may have endured a high degree of stress. Followers under such a leader will experience a state of psychological loss of resource. Resource loss may lead to employees entering the limp mode thus saving the resource in order to protect further resource loss. This resource deficiency among employees may inculcate the feeling of quitting the job resulting in the organisational resource loss. The resource conservation theory argues that the transition of resource from leader to follower will build psychological capital among subordinates. Resilience is characterised as an important component of psychological capital (Pan, Mao, Zhang, Wang, \& Su, 2017). Building upon these arguments, the following hypothesis was developed:

$\mathrm{H}_{4}$ : Employee resilience significantly mediates the relationship between servant leadership and employee turnover intentions.

Based on the above literature review, the following research model (Figure 1) was developed.

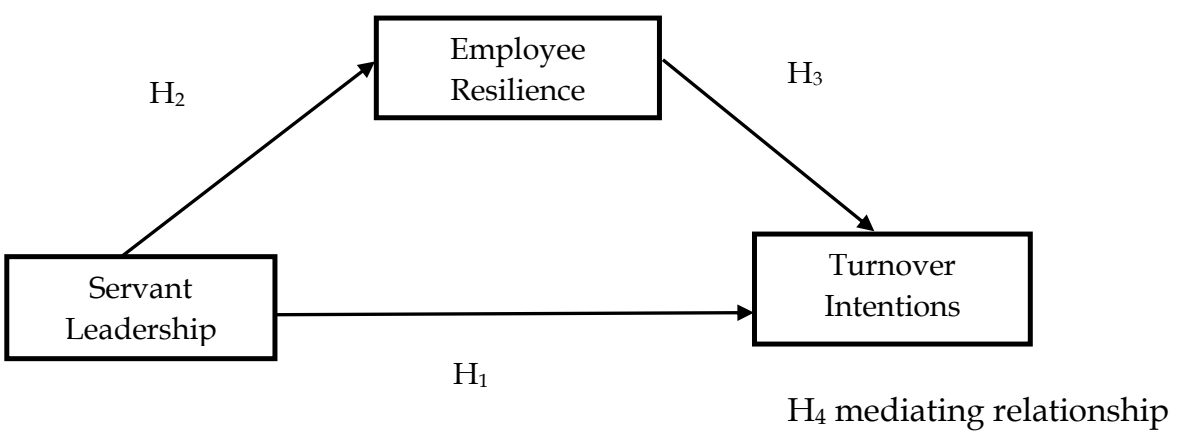

Figure 1: Research Model

\section{Research Methodology}

The study employed empirical research design to determine the impacts of servant leadership on employee turnover intention and mediating effect of employee resilience (Sekaran \& Bougie, 2016). Self-reported questionnaires were used to collect the data. All the items used to 
measure the constructs were adapted from the previous literature (Appendix 1) and measured using a 7-point Likert-scale. According to Chomeya (2010), the 7-point Likert-scale aims to have higher tendency to provide values of discrimination and reliability than the 5-point Likert-scale.

Prior to the actual data collection, we conducted a pilot study involving 30 lecturers, who also serve as a leader in their organisation. The aim of the pilot study is to check the internal consistency of the instruments used. For the actual data collection, 600 questionnaires were distributed to the target respondents. The study was delimited to the province of the Punjab and Federal Capital of Pakistan. Using stratified random sampling, a sample of 600 academics from six public universities was selected. Prior to the data collection, permission to conduct the study was requested from the management of all universities. Respondents were given a one-week time to complete the questionnaires before follow-up was made (Sekaran \& Bougie, 2016). Following the circulation of the questionnaires in about one week, a follow-up was carried out by telephone to obtain the completed questionnaire. Of the 600 questionnaires distributed, only a total of 301

Table 1: Respondents' Profiles

\begin{tabular}{lcc}
\hline Characteristic & Frequency & Percentage \\
\hline Gender & & \\
Male & 179 & 59.5 \\
Female & 122 & 40.5 \\
Age & & \\
55 above & 15 & 5.0 \\
$40-55$ & 115 & 38.2 \\
$25-39$ & 171 & 56.8 \\
Education & & \\
Master & 10 & 3.3 \\
M.Phil. & 182 & 60.5 \\
PhD & 104 & 34.6 \\
Post Doc & 5 & 1.7 \\
Designation & & \\
Lecturer & 156 & 51.8 \\
Assistant professor & 102 & 33.9 \\
Associate professor & 33 & 11.0 \\
Professor & 10 & 3.3 \\
\hline
\end{tabular}


usable questionnaires were returned, indicating a response rate of 50.1 per cent. A G* power analysis was conducted to determine the minimum sample size necessary to achieve a power level of 0.8 , as proposed by Cohen (1992). The $G^{*}$ Power 3.1 computed that the minimum sample size of 149 was required. Nevertheless, Awang, Wan Afthanorhan and Asri (2015) suggested a minimum sample size of 200 for covariance based structural equation modelling. Thus, the sample size of 301 was more than adequate to achieve the study objective. Of the total usable responses, 59.5 per cent (179) were male and 40.5 (122) were female. The majority of respondents (56.8\%) were $25-39$ years of age. More than half of them $(60 \%)$ possessed MPhil degree.

\section{Results}

To empirically test the research model and the associated hypotheses, we employed the covariance based structural equation modelling technique using Amos 24. To decrease the interactional impact of the measurement and structural model, we used a two-stage structural equation modeling technique (Byrne, 2010). In the first stage, we performed measurement model analysis to examine convergent and discriminant validity of the observed items and latent construct (Hair Jr., Matthews, Matthews, \& Sarstedt, 2017). Using the data imputation technique, a composite structural model was built from a measurement model. In the second stage, we examined the relationship between exogenous variables and endogenous variables using the composite structural model.

\subsection{Measurement Model Analysis}

As shown in Table 2, the measurement model fit with the data collected. All the indices used were between the recommended cut off values, in line with Whiting and Kline (2007).

Table 2: Measurement Model Fit

\begin{tabular}{lccc}
\hline Measure & Estimate & Threshold & Interpretation \\
\hline CMIN & 502.69 & - & - \\
DF & 249 & - & - \\
CMIN/DF & 2.019 & Between $1 \& 3$ & Excellent \\
CFI & 0.969 & $>0.95$ & Excellent \\
SRMR & 0.029 & $<0.08$ & Excellent \\
RMSEA & 0.058 & $<0.06$ & Excellent \\
\hline
\end{tabular}


Convergent validity was evaluated based on factor loadings, average variance extracted (AVE) and composite reliability (CR). As depicted in Table 3, with exception of SL3, ER1, ER2, ER3 and TO5, all the factor loadings in this study exceeded the recommended threshold values 0.5 (Awang, 2014). The five items loaded below 0.5 were removed from further analysis. The AVE and CR values of the constructs ranged

Table 3: Convergent Validity

\begin{tabular}{|c|c|c|c|c|}
\hline Variables & Items & Loadings & AVE & $\begin{array}{l}\text { Composite } \\
\text { Reliability }\end{array}$ \\
\hline $\begin{array}{l}\text { Servant } \\
\text { Leadership }\end{array}$ & $\begin{array}{l}\text { SL1 } \\
\text { SL2 } \\
\text { SL3 } \\
\text { SL4 } \\
\text { SL5 } \\
\text { SL6 } \\
\text { SL7 } \\
\text { SL8 } \\
\text { SL9 } \\
\text { SL10 } \\
\text { SL11 } \\
\text { SL12 } \\
\text { SL13 } \\
\text { SL14 }\end{array}$ & $\begin{array}{l}.874 \\
.860 \\
.408 \text { (deleted) } \\
.798 \\
.785 \\
.856 \\
.848 \\
.904 \\
.757 \\
.809 \\
.873 \\
.750 \\
.805 \\
.856\end{array}$ & 0.759 & 0.961 \\
\hline $\begin{array}{l}\text { Employee } \\
\text { Resilience }\end{array}$ & $\begin{array}{l}\text { ER1 } \\
\text { ER2 } \\
\text { ER3 } \\
\text { ER4 } \\
\text { ER5 } \\
\text { ER6 } \\
\text { ER7 } \\
\text { ER8 } \\
\text { ER9 } \\
\text { ER10 }\end{array}$ & $\begin{array}{l}.421 \text { (deleted) } \\
.413 \text { (deleted) } \\
.347 \text { (deleted) } \\
.877 \\
.852 \\
.815 \\
.777 \\
.897 \\
.818 \\
.783\end{array}$ & 0.823 & 0.957 \\
\hline $\begin{array}{l}\text { Turnover } \\
\text { Intentions }\end{array}$ & $\begin{array}{l}\text { TO1 } \\
\text { TO2 } \\
\text { TO3 } \\
\text { TO4 } \\
\text { TO5 }\end{array}$ & $\begin{array}{l}-.730 \\
-.702 \\
-.737 \\
-.842 \\
-.340 \text { (deleted) }\end{array}$ & 0.590 & 0.852 \\
\hline
\end{tabular}


from 0.590 to 0.823 , and 0.852 to 0.961 , respectively which also exceeded the recommended values (Hair Jr, Babin, \& Krey, 2017). These values indicate that the measurement model satisfies the convergent validity. We further analysed the discriminant validity by comparing the correlation values with the square root of the AVE values, as suggested by Fornell and Larcker (1981). As highlighted in Table 4, the square root of the AVE values were above the correlation of all the variables, providing an evidence of discriminant validity.

Table 4: Discriminant Validity

\begin{tabular}{lccccc}
\hline Variables & Mean & SD & $\begin{array}{c}\text { Servant } \\
\text { Leadership }\end{array}$ & $\begin{array}{c}\text { Employee } \\
\text { Resilience }\end{array}$ & $\begin{array}{c}\text { Turnover } \\
\text { Intentions }\end{array}$ \\
\hline Servant Leadership & 4.77 & 1.04 & $\mathbf{0 . 8 7 1}$ & & \\
Employee Resilience & 5.40 & 1.26 & $0.762^{* * *}$ & $\mathbf{0 . 9 0 8}$ & \\
Turnover intentions & 1.66 & 0.86 & $-0.521^{* * *}$ & $-0.596^{* * *}$ & $\mathbf{0 . 7 7 0}$ \\
\hline
\end{tabular}

Note: ${ }^{* *} \mathrm{p}<.05,{ }^{* * *} \mathrm{p}<.00$; figures in bold on the diagonal represent square root of average variance extracted.

\subsection{Estimating the Structural Model}

In order to test the hypothesis empirically, we constructed the structural equation model based on composite mean variables. As predicted, the result explicitly indicated that the servant leadership was positively related to employee resilience $(\beta=0.78, \mathrm{p}<0.01)$ and negatively associated to employee turnover intentions $(\beta=-0.56, \mathrm{p}<0.01)$. Therefore, $\mathrm{H}_{1}$ and $\mathrm{H}_{2}$ were supported. We also found that employee resilience were negatively related to employee turnover intentions $(\beta=$ $-0.54, \mathrm{p}<0.01)$ providing support for $\mathrm{H}_{3}$. Table 5 reports these results.

Table 5: Structural Model Results

\begin{tabular}{ccccc}
\hline Hypotheses & Relationships & Path Coefficients & t-values & Results \\
\hline $\mathrm{H}_{1}$ & $\mathrm{SL} \rightarrow \mathrm{TOI}$ & $-0.56^{* *}$ & -11.81 & Supported \\
$\mathrm{H}_{2}$ & $\mathrm{SL} \rightarrow \mathrm{ER}$ & $0.78^{* *}$ & 21.56 & Supported \\
$\mathrm{H}_{3}$ & $\mathrm{ER} \rightarrow \mathrm{TOI}$ & $-0.54^{* *}$ & -7.87 & Supported \\
\hline
\end{tabular}

Note: $\mathrm{SL}=$ Servant Leadership, $\mathrm{ER}=$ Employee Resilience, $\mathrm{TOI}=$ Turnover Intentions; ${ }^{* *} \mathrm{p}<0.01$. 


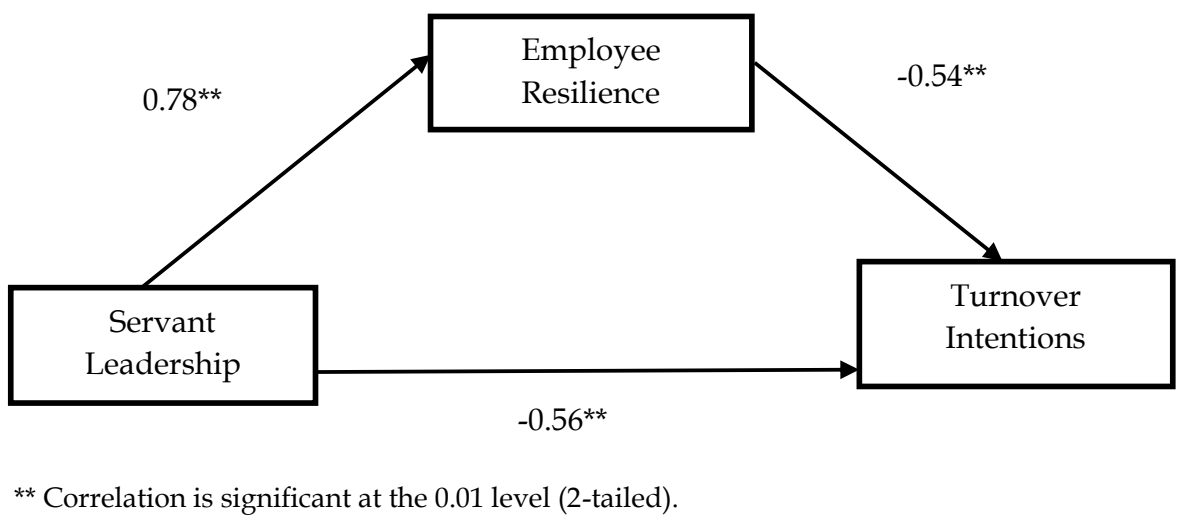

Figure 2: Results of the Structural Model

To test the mediation effect as formulated in $\mathrm{H}_{4}$, we followed the recommended bootstrapping bias-corrected confidence intervals suggested by Byrne (2010). Using Amos 23, we run 5000 bootstrapping samples to obtain the confidence interval. This procedure generated in a 95\% confidence interval. Table 6 shows the results of the mediation analysis. The mediation analysis shows a significant indirect effect of servant leadership on employee turnover intentions through employee resilience, supporting our predicted hypothesis $\mathrm{H}_{4}(\beta=-.42, \mathrm{p}<0.01)$. In the presence of employee resilience, the direct relationship between servant leadership and turnover intentions has become insignificant ( $\beta$ $=-0.14, \mathrm{p}>0.05)$, hence providing empirical evidence of full mediation.

Table 6: Results on Mediation Analysis

\begin{tabular}{lcccc}
\hline Path & Direct Effect & Total effect & Indirect Effect & Mediation \\
\hline $\mathrm{SL} \rightarrow \mathrm{ER} \rightarrow \mathrm{TOI}$ & $-0.14(\mathrm{p}>0.05)$ & $-0.56^{* * *}(\mathrm{p}<0.01)$ & $-0.42^{* * *}(\mathrm{p}<0.01)$ & Full mediation \\
\hline
\end{tabular}

\section{Discussion}

This study investigated the relationship between servant leadership, employees' turnover intentions and employee resilience. The outcomes derived from this study demonstrated that the servant leadership served as a crucial factor that reduced the turnover intentions among employees. This finding is in line with prior studies (Coetzer, Bussin, \& Geldenhuys, 2017; Schwarz, Newman, Cooper, \& Eva, 2016). Since there 
is a high level of interaction occurring with students, colleagues and administrators in HEI settings, there are many emotional demands that are generated, requiring higher levels of psychological efforts. This will eventually lead to a depletion of emotional resources that are commonly associated with negative outcomes such as burnout, dissatisfaction, decreased enthusiasm and withdrawal syndrome. This could plausibly be the reason for the significant relationship.

Results also showed that servant leadership, which placed employees' interests above their own, was highly needed in the Pakistani context. Through this type of leadership, academics feel more empowered and much appreciated, as they are treated equally, and have the opportunity to develop their skills and knowledge. It indicates that in the HEI setting, a supportive environment that promotes the articulation of thoughts, feelings and experiences are important. It appears that leaders who are friendly, approachable, honest, humble are respected and able to cushion the negative feelings of a follower (Cha, Calleja, Mendoza, Yupangco, \& Ferrer, 2019). In order to return the leaders' supports, academics exhibit a higher level of commitment and work engagement; and thus feel less incline to quit. This highlights that the autocratic style of leadership that dominates Pakistan's organisational culture may no longer be relevant today in the HEI setting. Autocratic leaders who dominate interactions, make decisions on their own and do not provide support for their followers may not be able to motivate the academics to engage in their work.

It is also worth noting that the servant leadership would promote employee resilience. From the perspective of COR theory, employee resilience is considered as organisational resources that can be developed, maintained and enhanced through appropriate human resource practice, including leadership. For an employee to build resilience, it is deemed important for employees to be aware of their personal assets, such as talents, skills and social networks (Bardoel, Pettit, De Cieri, \& Mcmillan, 2014). Thus, it is not surprising that having servant leaders will facilitate in enhancing employees resilience, as these types of leaders would utilise organisational resources to provide all means of support to employees. For instance, they will be more willing to provide training opportunities for followers, to up skills and develop them. Servant leaders who are characterised as individuals who tend to collaborate, show empathy, care and appreciation, will help followers cope with the negative events and manage their stress and workload positively. In this regard, any organisational change would be more positive for 
the followers. With a desire for a better regional and global university ranking, Pakistan has started to reform its higher education system since 2002 (Javed, Ahmad, \& Khahro, 2020).

The change in the country's education system will result in higher emotional demands, which may pressure the academics mentally and physically. Thus, without the support from servant leadership, they will not be able to increase their resilience. Thus, it is not surprising that resilient employees are much better equipped to cope with a constantly changing workplace. They will become more emotionally stable when faced with adversity and more open to new experiences. Due to this, they will attempt to accommodate the workplace change and stay working with the organisation, although they may not prefer such change. As a consequence, it is possible that the impact of servant leadership on employees' turnover intention may be influenced by a mediating variable, namely employees' resilience. Therefore, we may safely argue that the servant leadership style helps build resilience among the academics to cope with work adversities and negative events; and academics who have high resilience tend to have lower intentions to quit.

\section{Conclusion, Research Implications and Future Directions}

This study has attempted to examine the relationship between servant leadership, employee resilience and turnover intention in the context of HEIs in Pakistan. As implied by the findings of this study, academics in the Pakistan universities need servant leadership as an encouragement for them to stay with the current organisation. This issue is prevalent considering that academics within the country not only have desire to switch to other local universities, but also have a greater tendency to find better job opportunities in other countries, especially in developed regions. Hence, to promote employees retention, the leaders in the universities need to be willing to apply the servant leadership styles. Through the emotional, instrumental and social support provided by the servant leaders, academics would be able to generate higher levels of energy and would be better able to assimilate ideas and develop critical thinking skills. Under such leadership, the universities in Pakistan will be able to build a trustworthy relationship between leaders and followers, which would make them more motivated to work, feel more confident and competent. We also argue that employees' resilience may be a valuable resource for the academics, especially in today's turbulent 
environment. Recent health and safety threats such as Covid-19, for example, can have a great impact on the well-being of employees. Employee assistance and support in this case can help the employees to cope better with such situation, and cushion their stress. This suggests that universities should incorporate servant leadership characteristics when grooming academic leaders.

From the theoretical perspective, this study extends the body of literature by providing empirical evidence on the applicability of COR theory in the area of human resource practice. It sought to establish the relevance of employees' resilience as a mediator intervened in the relationship between servant leadership and employee's turnover intention. We argue that the most effective way to promote the positive impacts of servant leadership lies in the employee resilience.

While this study provides insight into the role of servant leadership in the educational setting, it is not without limitations. First, the samples of the respondents are confined to employees in the HEI sector. Future research can extend on the population, including those from different industries. Second, this study focuses only on one Asian country, Pakistan. Future research may conduct a comparative analysis of the different ASEAN nations, provided that different Asian countries have different dominant cultures and values, which may have some impact on the values and perceptions of the leadership styles. Due to limitation of time and money, we are unable to follow a time lag design that is more suitable for mediation model testing (Deboeck \& Preacher, 2016).

\section{References}

Awang, Z. (2014). A handbook on SEM for academicians and practitioners: The step by step practical guides for the beginners. Kuala Lumpur: MPSW Rich Resources.

Awang, Z., Wan Afthanorhan, W.M.A., \& Asri, M.A.M. (2015). Parametric and non parametric approach in structural equation modeling (SEM): The application of bootstrapping. Modern Applied Science, 9(9), 58-67. http:// dx.doi.org/10.5539/mas.v9n9p58

Bardoel, E.A., Pettit, T.M., De Cieri, H., \& Mcmillan, L. (2014). Employee resilience: An emerging challenge for HRM. Asia Pacific Journal of Human Resources, 52(3), 279-297. http://dx.doi.org/10.1111/1744-7941.12033

Barbuto, J.E., \& Gottfredson, R.K. (2016). Human capital, the Millennial's reign, and the need for servant leadership. Journal of Leadership Studies, 10(2), 5963. http://dx.doi.org/10.1002/jls.21474

Barbuto, J.E., Gottfredson, R.K., \& Searle, T.P. (2014). An examination of emotional intelligence as an antecedent of servant leadership. Journal of 
Leadership and Organizational Studies, 21(3), 315-323. http://dx.doi.org/ $10.1177 / 1548051814531826$

Barbuto, J.E., \& Wheeler, D.W. (2006). Scale development and construct clarification of servant leadership. Group and Organization Management, 31(3), 300326. http://dx.doi.org/10.1177/1059601106287091

Beck, R., \& Harter, J. (2015). Managers account for $70 \%$ of variance in employee engagement. Retrieved from https://news.gallup.com/businessjournal/ 182792/managers-account-variance-employee-engagement.aspx

Bhamra, R., Dani, S., \& Burnard, K. (2011). Resilience: The concept, a literature review and future directions. International Journal of Production Research, 49(18), 5375-5393. http://dx.doi.org/10.1080/00207543.2011.563826

Brohi, N.A., Jantan, A.H., Qureshi, M.A., Jaffar, A.R.B., Ali, J.B., \& Ab Hamid, K.B. (2018). The impact of servant leadership on employees attitudinal and behavioural outcomes. Cogent Business \& Management, 5(1), 1-17. http:// dx.doi.org/10.1080/23311975.2018.1542652

Byrne, B.M. (2010). Structural equation modeling with AMOS: Basic concepts, applications, and programming (multivariate applications series). New York, NY: Taylor \& Francis Group.

Cha, J.C., Calleja, J.T., Mendoza, P.G., Yupangco, J.L., \& Ferrer, R.C. (2019). Impact of leadership style and demographic profile on accounting student performance - the case of academic administrators and faculty members in the Philippines. Asian Journal of Business and Accounting, 12(2), 179-210. http://dx.doi.org/10.22452/ajba.vol12no2.7

Chen, S., Westman, M., \& Hobfoll, S.E. (2015). The commerce and crossover of resources: Resource conservation in the service of resilience. Stress and Health, 31(2), 95-105. http://dx.doi.org/10.1002/smi.2574

Chomeya, R. (2010). Quality of psychology test between Likert scale 5 and 6 points. Journal of Social Sciences, 6(3), 399-403.

Coetzer, M., Bussin, M., \& Geldenhuys, M. (2017). The functions of a servant leader. Administrative Sciences, 7(1), 1-32. http://dx.doi.org/10.3390/ admsci7010005

Cohen, J. (1992). A power primer. Psychological Bulletin, 112(1), 155-159. http:// dx.doi.org/10.1037/0033-2909.112.1.155

Coomber, B., \& Barriball, K.L (2007). Impact of job satisfaction components on intent to leave and turnover for hospital-based nurses: A review of the research literature. International Journal of Nursing Studies, 44(2), 297-314. http://dx.doi.org/10.1016/j.ijnurstu.2006.02.004

Cooper, C.L., Liu, Y., \& Tarba, S.Y. (2014). Resilience, HRM practices and impact on organizational performance and employee well-being. The International Journal of Human Resource Management, 25(17), 2466-2471. http:// dx.doi.org/10.1080/09585192.2014.926688

De Clercq, D., Bouckenooghe, D., Raja, U., \& Matsyborska, G. (2014). Servant leadership and work engagement: The contingency effects of leader- 
follower social capital. Human Resource Development Quarterly, 25(2), 183212. http://dx.doi.org/10.1002/hrdq.21185

Deboeck, P.R., \& Preacher, K. J. (2016). No need to be discrete: A method for continuous time mediation analysis. Structural Equation Modeling: A Multidisciplinary Journal, 23(1), 61-75. http://dx.doi.org/10.1080/10705511. 2014.973960

Eva, N., Robin, M., Sendjaya, S., van Dierendonck, D., \& Liden, R.C. (2019). Servant leadership: A systematic review and call for future research: The leadership quarterly yearly review for 2019. Leadership Quarterly, 30(1), 111132. http://dx.doi.org/10.1016/j.leaqua.2018.07.004

Fornell, C., \& Larcker, D.F. (1981). Structural Equation Models with Unobservable Variables and Measurement Error: Algebra and Statistics. Journal of Marketing Research, 18(3), 382-388. http:/ / dx.doi.org/10.2307/3150980

Greenleaf, R.K. (1977). Servant leadership: A journey into the nature of legitimate power and greatness. Mahwah, NJ: Paulist Press.

Griffeth, R.W., Hom, P.W., \& Gaertner, S. (2000). A meta-analysis of antecedents and correlates of employee turnover: Update, moderator tests, and research implications for the next millennium. Journal of Management, 26(3), 463-488. http://dx.doi.org/10.1177/014920630002600305

Hair Jr, J.F., Babin, B.J., \& Krey, N. (2017). Covariance-based structural equation modeling in the Journal of Advertising: Review and recommendations. Journal of Advertising, 46(1), 163-177. http://dx.doi.org/10.1080/00913367.2 017.1281777

Hair Jr., J.F., Matthews, L.M., Matthews, R.L., \& Sarstedt, M. (2017). PLS-SEM or CB-SEM: Updated guidelines on which method to use. International Journal of Multivariate Data Analysis, 1(2), 107-123. http://dx.doi.org/10.1504/ ijmda.2017.10008574

Harris, R.B., Harris, K.J., \& Harvey, P. (2008). An examination of the impact of supervisor on the relationship between job strains and turnover intention for computer workers. Journal of Applied Social Psychology, 38(8), 2108-2131. http://dx.doi.org/10.1111/j.1559-1816.2008.00383.x

Hobfoll, S.E. (2011). Conservation of resource caravans and engaged settings. Journal of Occupational and Organizational Psychology, 84(1), 116-122. http:// dx.doi.org/10.1111/j.2044-8325.2010.02016.x

Hobfoll, S.E., Halbesleben, J., Neveu, J.-P., \& Westman, M. (2018). Conservation of resources in the organizational context: The reality of resources and their consequences. Annual Review of Organizational Psychology and Organizational Behavior, 5, 103-131. http://dx.doi.org/10.1146/annurevorgpsych-032117-104640

Ice, J.W. (2017). A servant leader's impact on employee psychological capital: What is the relationship of an employee's perception of their manager's servant leader behaviors on their reported psychological capital? (Doctoral thesis, PointPark University, Pittsburgh). 
International Labour Organization (2019). World employment and social outlook: Trends 2019. Retrieved from https://www.ilo.org/wcmsp5/groups/ public/---dgreports/---dcomm/---publ/documents/publication/wcms_ 670542.pdf

Ismail, N.H., \& Arma, N. (2016). Occupational stress and its associated factors among academician in a research university, Malaysia. Malaysian Journal of Public Health Medicine, 16(1), 81-91.

Javed, Y., Ahmad, S., \& Khahro, S.H. (2020). Evaluating the research performance of Islamabad-based higher education institutes. SAGE Open, 10(1), 1-11. http://dx.doi.org/10.1177/2158244020902085

Jo, V.H. (2008). Voluntary turnover and women administrators in higher education. Higher Education, 56(5), 565-582. http://dx.doi.org/10.1007/ s10734-008-9111-y

Knani, M., Fournier, P.S., \& Biron, C. (2018). Psychosocial risks, burnout and intention to quit following the introduction of new software at work. Work, 60(1), 95-104. http://dx.doi.org/10.3233/WOR-182714

Kashyap, V., \& Rangnekar, S. (2016). Servant leadership, employer brand perception, trust in leaders and turnover intentions: A sequential mediation model. Review of Managerial Science, 10(3), 437-461. http://dx.doi. org/10.1007/s11846-014-0152-6

Khalid, S., Irshad, M.Z., \& Mahmood, B. (2012). Job satisfaction among academic staff: A comparative analysis between public and private sector universities of Punjab, Pakistan. International Journal of Business and Management, 7(1), 126-136. http:// dx.doi.org/10.5539/ijbm.v7n1p126

Liden, R.C., Wayne, S.J., Zhao, H., \& Henderson, D. (2008). Servant leadership: Development of a multidimensional measure and multi-level assessment. Leadership Quarterly, 19(2), 161-177. http://dx.doi.org//10.1016/j.leaqua. 2008.01.006

Ling, Q., Lin, M., \& Wu, X. (2016). The trickle-down effect of servant leadership on frontline employee service behaviors and performance: A multilevel study of Chinese hotels. Tourism Management, 52, 341-368. http://dx.doi. org/10.1016/j.tourman.2015.07.008

Liu, Z., Cai, Z., Li, J., Shi, S., \& Fang, Y. (2013). Leadership style and employee turnover intentions: A social identity perspective. Career Development International, 18(3), 305-324. http:/ / dx.doi.org/10.1108/CDI-09-2012-0087

Luthans, F., Luthans, K.W., \& Luthans, B.C. (2004). Positive psychological capital: Beyond human and social capital. Business Horizons, 47(1), 45-50. http://dx.doi.org/10.1016/j.bushor.2003.11.007

Majeed, N., Ramayah, T., Mustamil, N., Nazri, M., \& Jamshed, S. (2017). Transformational leadership and organizational citizenship behavior: Modeling emotional intelligence as mediator. Management and Marketing. Challenges for the Knowledge Society, 12(4), 571-590. http://dx.doi.org/10.1515/ mmcks-2017-0034 
McGonagle, A.K., Fisher, G.G., Barnes-Farrell, J.L., \& Grosch, J.W. (2015). Individual and work factors related to perceived work ability and labor force outcomes. Journal of Applied Psychology, 100(2), 376-398. http://dx.doi. org $/ 10.1037 / \mathrm{a} 0037974$

Ministry of Finance, Government of Pakistan (2016). Pakistan economic survey (2015-16). Retrieved from http://www.finance.gov.pk/survey_1516.html

Neubert, M.J., Hunter, E.M., \& Tolentino, R.C. (2016). A servant leader and their stakeholders: When does organizational structure enhance a leader's influence? The Leadership Quarterly, 27(6), 896-910. http://dx.doi.org/ 10.1016/j.leaqua.2016.05.005

Nguyen, Q., Kuntz, J.R.C., Näswall, K., \& Malinen, S. (2016). Employee resilience and leadership styles: The moderating role of proactive personality and optimism. New Zealand Journal of Psychology, 45(2), 13-21.

Othman, N., Ghazali, Z., \& Nasurdin, A.M. (2017, October). Nurse engagement: Examining the role of resilience. Paper presented at the 4th Conference on Business Management, Penang, Malaysia.

Othman, N., \& Nasurdin, A.M. (2011). Work engagement of Malaysian nurses: Exploring the impact of hope and resilience. World Academy of Science, Engineering and Technology, 60, 1702-1706.

Pan, X., Mao, T., Zhang, J., Wang, J., \& Su, P. (2017). Psychological capital mediates the association between nurses' practice environment and work engagement among Chinese male nurses. International Journal of Nursing Sciences, 4(4), 378-383. http://dx.doi.org/10.1016/j.ijnss.2017.09.009

Parris, D.L., \& Peachey, J.W. (2013). Encouraging servant leadership: A qualitative study of how a cause-related sporting event inspires participants to serve. Leadership, 9(4), 486-512. http://dx.doi.org/10.1177/17427 15012470675

Schwarz, G., Newman, A., Cooper, B., \& Eva, N. (2016). Servant leadership and follower job performance: The mediating effect of public service motivation. Public Administration, 94(4), 1025-1041. http://dx.doi.org/10.1111/ padm.12266

Sekaran, U., \& Bougie, R. (2016). Research methods for business: A skill-building approach. Hoboken, NJ: John Wiley \& Sons.

Sendjaya, S. (2015). Personal and organizational excellence through servant leadership: Learning to serve, serving to lead, leading to transform. Switzerland: Springer. http://dx.doi.org/10.1007/978-3-319-16196-9

Walumbwa, F.O., Hartnell, CA., \& Oke, A. (2010). Servant leadership, procedural justice climate, service climate, employee attitudes, and organizational citizenship behavior: A cross-level investigation. Journal of Applied Psychology, 95(3), 517-529. http://dx.doi.org/10.1037/a0018867

Walumbwa, F.O., Mayer, D.M., Wang, P., Wang, H., Workman, K., \& Christensen, A.L. (2011). Linking ethical leadership to employee performance: The roles of leader-member exchange, self-efficacy, and organizational 
identification. Organizational Behavior and Human Decision Processes, 115(2), 204-213. http://dx.doi.org//10.1016/j.obhdp.2010.11.002

Whiting, H.J., \& Kline, T.J. (2007). Testing a model of performance appraisal fit on attitudinal outcomes. The Psychologist-Manager Journal, 10(2), 127-148. http:/ /dx.doi.org/10.1080/10887150701451288

Wongboonsin, K., Dejprasertsri, P., Krabuanrat, T., Roongrerngsuke, S., Srivannaboon, S., \& Phiromswad, P. (2018). Sustaining employees through coworker and supervisor support: Evidence from Thailand. Asian Journal of Business and Accounting, 11(2), 187-214.

Ye, Y., Lyu, Y., \& He, Y. (2019). Servant leadership and proactive customer service performance. International Journal of Contemporary Hospitality Management, 31(3), 1330-1347. http:/ / dx.doi.org//10.1108/IJCHM-03-2018-0180 
